\title{
KEEFEKTIFAN LEMBAGA PASAR LELANG CABAI MERAH DI KECAMATAN PANJATAN KABUPATEN KULON PROGO
}

\section{The Effectiveness of Auction Market Institution for Red Chili in Panjatan District Kulon Progo Regency}

\author{
Patrianisya Devi ${ }^{1}$, Harsoyo $^{1}$, Subejo $^{1}$ \\ ${ }^{1}$ Fakultas Pertanian Universitas Gadjah Mada
}

\begin{abstract}
Research was done in Panjatan District Kulon Progo Regency aimed to know the effectiveness of auction market institution for red chili in Panjatan District and also to know the factors which influence to the effectiveness of auction market institution for red chili. This research used descriptive analytic method. District, subdistrict, and farmer groups were taken by Purposive method. Sample members were taken from every farmer group sample by using Simple Random Sampling with total amount of 60 farmers. Data were analized by Proportion Test and Multiple Regression Analysis. The results of research showed that the most of farmer in Panjatan District Kulon Progo Regency have perception that the auction market institution for red chili has a high effectiveness. Farmer's attitude and farmer group leader role give positive influence to the effectiveness of auction market institution for red chili, education level of farmers give negative influence to the effectiveness of auction market institution for red chili, whereas age, motivation, and the selling price of chili do not influence to the effectiveness of auction market institution.
\end{abstract}

\section{Keywords : Effectiveness, Auction Market, Coastal Farming Land, Kulon Progo}

\section{INTISARI}

Penelitian ini dilakukan di Kecamatan Panjatan Kabupaten Kulon Progo dengan tujuan untuk mengetahui tingkat keefektifan lembaga pasar lelang cabai merah di Kecamatan Panjatan dan mengetahui faktor-faktor yang mempengaruhi keefektifan lembaga pasar lelang cabai merah. Metode yang digunakan dalam penelitian ini menggunakan metode deskriptif analitik. Pengambilan sampel kecamatan, desa, dan kelompok tani menggunakan metode purposive. Sampel anggota diambil dari masing-masing sampel kelompok tani secara Simple Random Sampling sehingga total sampel 60 petani. Data dianalisis dengan metode Uji Proporsi dan Regresi Linear Berganda. Hasil penelitian menunjukkan bahwa sebagian besar besar petani di Kecamatan Panjatan Kabupaten Kulon Progo memiliki persepsi bahwa lembaga pasar lelang cabai merah memiliki keefektifan yang tinggi. Sikap petani dan peran ketua kelompok berpengaruh positif pada keefektifan lembaga pasar lelang cabai merah, tingkat pendidikan petani berpengaruh negatif terhadap keefektifan lembaga, sedangkan umur, motivasi, dan harga jual cabai merah tidak berpengaruh pada keefektifan lembaga pasar lelang cabai merah.

Kata Kunci: Keefektifan, Pasar Lelang, Lahan Pasir, Kulon Progo

\section{PENDAHULUAN}

Indonesia merupakan negara agraris yang cocok untuk budidaya tanaman cabai. Cabai (Capsicum annum L) merupakan salah satu komoditas sayuran yang banyak dibudidayakan oleh petani di Indonesia. Hampir seluruh masyarakat Indonesia menggunakan cabai dalam setiap masakan mereka. Oleh karena itu cabai dapat dikatakan sebagai salah satu komoditas yang menjadi kebutuhan pokok masyarakat Indonesia. Salah satu jenis cabai yang banyak dicari konsumen yaitu cabai merah. Tanaman cabai merah mampu ditanam baik di berbagai lahan. Salah satu daerah yang potensial untuk budidaya tanaman cabai merah yaitu pada lahan pasir pantai.

Kulon Progo adalah salah satu kabupaten yang memiliki lahan pasir pantai yang cukup luas dan sesuai untuk budidaya cabai merah, tepatnya di Kecamatan Panjatan. Sebagian besar penduduk di pesisir pantai Kecamatan Panjatan bermata pencaharian sebagai petani yang menggantungkan hidup melalui budidaya cabai merah. Cabai merah menjadi komoditas utama petani lahan pasir pantai disamping tanaman hortikultura lain seperti melon dan semangka.

Cabai merah juga merupakan salah satu produk pertanian yang rentan mengalami fluktuasi 
harga. Harga bisa melonjak tinggi namun bisa juga berubah sangat rendah. Permainan harga oleh para tengkulak (pedagang pengumpul) menjadi hal yang sangat merugikan petani cabai merah di lahan pasir pantai. Salah satu solusi untuk menekan anjloknya harga cabai merah yaitu dengan adanya kelembagaan pasar lelang.

Kecamatan Panjatan memiliki komunitas petani lahan pasir pantai yang telah mendirikan beberapa pasar lelang cabai merah di beberapa desa. Menurut Supriyanto, et al. (2012) dalam penelitiannya mengenai pengorganisasian pasar lelang secara umum menunjukkan hasil bahwa pasar lelang memberikan keuntungan bagi petani ditilik dari segi sosial maupun ekonomi.

Komunitas petani lahan pasir pantai di Kecamatan Panjatan telah mengembangkan pasar lelang cabai merah dengan manajemen yang relatif sederhana dan terus berkembang. Kelembagaan pasar lelang ini dipelopori dan dikelola sendiri oleh angggota kelompok tani yang menjadi pengurus pasar lelang. Dengan demikian, kelembagaan kelompok tani sangat mempengaruhi kelembagaan pasar lelang dan keefektifan dari pasar lelang itu sendiri.

Para ahli berpendapat bahwa lembaga dapat diartikan sebagai suatu norma/ kaidah peraturan atau organisasi yang memudahkan koordinasi dalam membentuk harapan masing-masing yang mungkin dapat dicapai dengan saling bekerja sama (Rintuh \& Miar, 2003).

Lembaga pasar lelang jika dikelola dengan baik dapat memberikan manfaat yang sangat tinggi bagi para petani cabai merah. Keberhasilan suatu pasar tidak semata-mata ditentukan oleh tersedianya barang dan pembeli, namun juga pengorganisasian lembaga dan pemasaran itu sendiri. Apabila bisa diorganisasikan dengan baik, pasar lelang bisa menjadi senjata utama dalam menekan fluktuasi harga cabai merah yang sering menjadi momok bagi petani. Berdasarkan hal tersebut maka perlu diketahui sejauh mana keefektifan lembaga pasar lelang cabai merah ini, serta perlu diketahui apa saja faktor yang mempengaruhinya..

\section{TINJAUAN PUSTAKA}

Secara konvensional pasar adalah tempat berlangsungnya transaksi jual beli komoditi (barang dan jasa) antara penjual dan pembeli yang merupakan pelaku utama pasar. Penjual dan pembeli menjadi penentu harga secara benar sesuai dengan kekuatan tawar menawar mereka masing-masing. Pihak-pihak lainnya seperti pemerintah mempunyai peran yang tidak hanya sebagai provider yang memfasilitasi transaksi yang efisien dan efektif sehingga berlangsung aman, transparan lancar, dan terkendali (Martius, 2008).

Kelembagaan pasar lelang secara konsepsional merupakan penyelenggara transaksi perdagangan komoditas agro sebagai upaya penemuan harga yang terbuka, transparan dan terbaik, memberikan perlindungan nilai, serta peningkatan efisiensi perdagangan. Konsep tersebut telah dijabarkan dalam ketentuan penyelenggaraan Pasar Lelang Forward. Penentuan harga ditentukan sebagai konskuensi pertemuan kekuatan supply dan demand pada titik keseimbangan harga pasar. Melalui informasi yang lengkap baik tentang harga, mutu dan kuantitas, sehingga biaya transaksi dianggap nol dan pasar adalah sebagai solusi yang efisien. Demikian pula dalam hal penemuan harga; terjadi proses kesepahaman antara penjual dan pembeli pada tingkat harga pasar yang disepakati yang memungkinkan terjadinya transaksi (Damoma, et al., 2013).

Pasar lelang sebenarnya merupakan pasar yang diatur untuk menyeimbangkan pengetahuan antar pelaku, mengurangi kemungkinan terjadinya under value pada suatu barang tertentu, dan dapat menciptakan mekanisme penentuan harga yang terbuka. Dengan demikian, pada dasarnya pasar lelang ditujukan untuk menciptakan transparansi harga melalui mekanisme tawar-menawar langsung antara penjual dan pembeli (Hartono et al., 1996).

Fungsi pasar lelang adalah mempertemukan antar pedagang (pembeli) kepada komoditas yang ditawarkan oleh kelompok tani. Tampak bahwa peran terpenting pasar lelang sangat terkait dengan informasi harga pasar yang terjadi dengan patokan di tingkat pasar induk. Fungsi lain dari pasar lelang adalah melakukan fungsi pelelangan atau mengatur sepenuhnya proses transaksi antara petani yang diwakili kelompok tani dengan beberapa pedagang, melalui ketentuan yang telah disepakati sebelumnya. Selain memberikan informasi harga dan menjembatani proses transaksi tersebut, pasar lelang juga harus menjadi penghubung lembaga antara petani dengan lembaga keuangan, dalam merekomendasikan jumlah modal yang dibutuhkan sesuai dengan jumlah produksi yang dapat dijual atau dipasarkan (Anugrah, 2004). 
Menurut Departemen Pedagangan cit. Hartono et al. (1996), fungsi pasar lelang dalam menentukan harga dapat berjalan secara efektif bila (a) terdapat pengetahuan dan informasi yang memadai mengenai mutu produk yang dipasarkan sehingga diperlukan suatu mekanisme grading dan sortasi secara penampakan fisik dari barang yang ditawarkan, (b) pembeli potensial bersedia melakukan transaksi di pasar lelang sehingga perlu adanya layanan dari pasar lelang kepada pembeli, (c) pasar lelang harus cukup besar yang antara lain dapat dicapai dengan mengembangkan pola pasar lelang sebagai kegiatan koperasi petani produsen, (d) tidak ada kolusi harga diantara pembeli, (e) terdapat transparansi harga secara geografis, dan (f) adanya mekanisme untuk dapat mengikuti proses perubahan harga dalam lelang.

Efektif menurut Kamus Besar Bahasa Indonesia berarti ada efeknya (akibatnya, pengaruhnya, kesannya) serta dapat membawa hasil (berhasil guna). Sedangkan keefektifan menurut Kamus Besar Bahasa Indonesia yaitu menjadikan efektif. Keefektifan atau efektivitas biasanya berkaitan dengan perbandingan antara tingkat pencapaian tujuan dengan rencana yang telah disusun sebelumnya.

Bagi seorang ahli ekonomi atau analis keuangan, efektivitas organisasi adalah keuntungan atau laba investasi. Bagi seorang manajer produksi, efektivitas seringkali berarti kuantitas atau kualitas keluaran (output) barang atau jasa. Bagi seorang ilmuan bidang riset, efektivitas dijabarkan dengan jumlah paten, penemuan atau produk baru suatu organisasi. Dan bagi sejumlah sarjana ilmu sosial, efektivitas seringkali ditinjau dari sudut kualitas kehidupan pekerja. Singkatnya pengertian efektivitas organisasi memiliki arti yang berbedabeda bagi setiap orang, bergantung pada kerangka acuan yang dipakai (Steers, 1985).

Lipham dan Hoeh cit. Mulyasa (2003) meninjau efektivitas adalah suatu kegiatan dari faktor pencapaian tujuan, yang memandang bahwa efektivitas berhubungan dengan pencapaian tujuan bersama bukan pencapaian tujuan pribadi. Suatu organisasi dan lembaga dikatakan efektif jika tujuan bersama dapat dicapai dan belum bisa dikatakan efektif meskipun tujuan individu yang ada didalamnya dapat terpenuhi.

Efektivitas organisasi dalam pencapaian tujuan-tujuan organisasi adalah kunci darikesuksesan suatu organisasi. Istilah efektivitas itu sendiri sangat bervariatif dimana penjelasannya dapat menyangkut berbagai dimensi yang memusatkan perhatian kepada berbagai kriteria evaluasi. Selanjutnya pengukurannya relatif beraneka ragam dimana kriteria yang berbeda dilakukan secara serempak. Efektivitas adalah ukuran berhasil tidaknya pencapaian tujuan organisasi. Apabila suatu organisasi berhasil mencapai tujuannya, maka organisasi tersebut telah berjalan dengan efektif (Stoner cit. Monoarfa, 2012).

Konsep efektivitas/ keefektifan memiliki makna yang berbeda dan kriteria yang berbeda-beda tergantung pada kerangka acuan yang digunakan serta situasi dan kondisi wilayah yang akan diteliti. Menurut Steers (1985), ukuran-ukuran unvariasi untuk efektivitas organisasi antara lain :

a. Efektivitas keseluruhan, sejauh mana organisasi melaksanakan seluruh tugas pokoknya atau mencapai semua sasarannya.

b. Kualitas, kualitas dari jasa atau produk primer yang dihasilkan oleh organisasi.

c. Produktivitas, kuantitas atau volume dari produk atau jasa pokok yang dihasilkan organisasi. Dapat diukur menurut 3 tingkatan: tingkat individual, kelompok dan keseluruhan organisasi. Ini bukan ukuran dari efisiensi, tidak ada perhitungan nisbah biaya dan keluaran.

d. Kesiagaan, penilaian menyeluruh sehubungan dengan kemungkinan, bahwa organisasi mampu menyelesaikan sesuatu tugas khusus dengan baik jika diminta.

e. Efisiensi, nisbah yang mencerminkan perbandingan beberapa aspek prestasi unit terhadap biaya untuk menghasilkan prestasi tersebut.

f. Laba atau penghasilan

g. Pertumbuhan, penambahan dalam hal-hal seperti tenaga kerja, fasilitas pabrik, harga, penjualan, laba, bagian pasar, dan penemuan baru.

h. Pemanfaatan lingkungan

i. Stabilitas, pemeliharaan struktur, fungsi, dan sumber-daya sepanjang waktu.

j. Perputaran atau keluar masuknya pekerja

k. Kemangkiran

1. Kecelakaan, frekuensi dalam pekerjaan yang berakibat kerugian waktu

m. Semangat kerja

n. Motivasi 
o. Kepuasan, tingkat kepuasan yang dirasakan seseorang atas peranan atau pekerjaannya dalam organisasi.

p. Penerimaan tujuan organisasi

q. Kepaduan konflik-konflik kompak, dimensi berkutub dua, yang dimaksud kutub kepaduan adalah fakta bahwa para anggota organisasi saling menyukai satu sama lain, bekerja sama dengan baik, berkomunikasi sepenuhnya dan secara terbuka, dan dapat mengkoordinasikan usaha kerja mereka. Pada kutub yang lain terdapat organisasi penuh pertengkaran baik dalan bentuk kata-kata maupun secara fisik, koordinasi yang buruk, dan komunikasi yang tidak efektif.

r. Keluwesan adaptasi, kemampuan sebuah organisasi untuk mengubah prosedur standar operasinya jika lingkungannya berubah, untuk mencegah kebekuan terhadap rangsangan lingkungan.

s. Penilaian oleh pihak luar

Menurut Sharma cit. Monoarfa (2012), kriteria atau ukuran suatu efektivitas dapat dinilai dari produktivitas organisasi atau output, fleksibilitas organisasi dan bentuk keberhasilannya dalam menyesuaikan diri dengan perubahan-perubahan di dalam dan di luar organisasi, serta dari ada tidaknya ketegangan dalam organisasi atau hambatan-hambatan konflik di antara bagian-bagian organisasi.

\section{METODE PENELITIAN}

Metode dasar yang dipakai dalam penelitian ini adalah deskriptif analitik. Tujuan dari penelitian deskriptif adalah untuk membentuk deskripsi, gambaran atau lukisan secara sistematis, faktual,

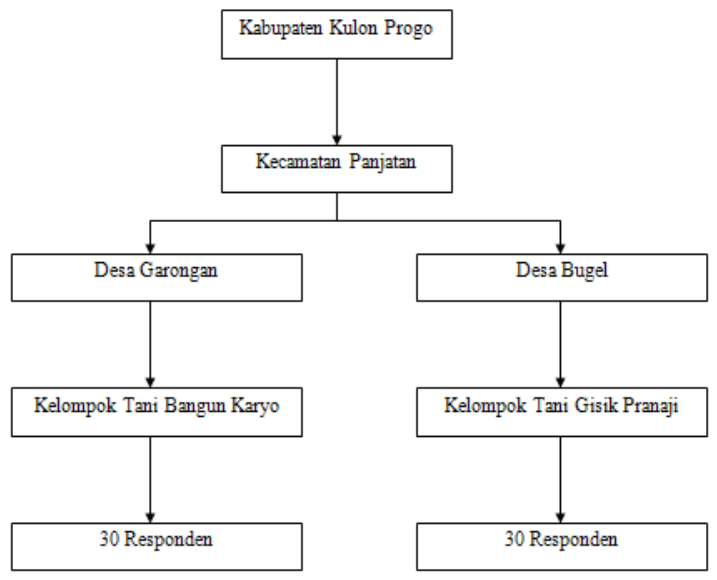

Gambar 1 Metode Pengambilan Sampel dan akurat mengenai fakta-fakta, sifat-sifat serta hubungan antar fenomena yang diselidiki. Dalam pelaksanaan penelitian, penelitian ini menggunakan metode penelitian survei, yaitu penyelidikan yang diadakan untuk memperoleh fakta-fakta dari gejalagejala yang ada dan mencari keterangan-keterangan secara faktual. Metode survei menunjukkan hasil dari populasi, oleh karena itu sampel individu atau kelompok yang diteliti harus mewakili populasi.

\section{Uji Proporsi}

Ho : $\mathrm{P} \leq 50 \%$

$\mathrm{Ha}: \mathrm{P}>50 \%$

Dengan,

Ho : diduga kurang dari $50 \%$ petani memiliki persepsi bahwa lembaga pasar lelang cabai merah memiliki keefektifan yang tinggi

Ha : diduga lebih dari $50 \%$ petani memiliki persepsi bahwa lembaga pasar lelang cabai merah memiliki keefektifan yang tinggi

Taraf siginifikansi : $\alpha=0,05(5 \%), \mathrm{n}=60$

Statistik pengujian :

Z hitung $=\sqrt{\frac{\frac{x}{n}-P o}{\sqrt{\frac{P o(1-P o)}{n}}}}$

Keterangan :

$\mathrm{x}$ : Jumlah sampel petani yang menyebutkan lembaga pasar lelang memiliki keefektifan yang tinggi

$\mathrm{n} \quad$ : Jumlah keseluruhan petani sampel

Po : Keofisien keyakinan (50\%)

Kriteria pengujian:

Zhit $>$ ZTabel : Ho ditolak, Ha diterima

Zhit $\leq$ ZTabel : Ho diterima, Ha ditolak

\section{Analisis Regresi Linear Berganda}

$\mathrm{Y}=\mathrm{A}+\mathrm{b} 1 . \mathrm{X} 1+\mathrm{b} 2 . \mathrm{X} 2+\mathrm{b} 3 . \mathrm{X} 3+\mathrm{b} 4 \cdot \mathrm{X} 4+\mathrm{b} 5 . \mathrm{X} 5+$ b6.X6

Keterangan :

Y : Keefektifan lembaga pasar lelang

A : Nilai konstanta

b1-b6 : koefisien regresi

$\mathrm{X} 1$ : Umur

$\mathrm{X} 2$ : Tingkat Pendidikan

$\mathrm{X} 3$ : Sikap petani anggota

X4 : Motivasi petani 
X5 : Peran ketua kelompok tani

X6 : Harga jual cabai merah

Pengujian hipotesis :

Ho : $b_{1}=b_{2}=b_{3}=b_{4}=b_{5}=b_{6}=0$

Ha: $\quad b_{1} \neq b_{2} \neq b_{3} \neq b_{4} \neq b_{5} \neq b_{6} \neq 0$

Ho: Tidak ada pengaruh nyata antara umur, tingkat pendidikan, sikap anggota terhadap lembaga pasar lelang, motivasi petani menjual hasil produksi melalui pasar lelang, peran ketua kelompok, dan harga jual cabai merah dalam keefektifan lembaga pasar lelang.

Ha: Ada pengaruh nyata antara umur, tingkat pendidikan, sikap anggota terhadap lembaga pasar lelang, motivasi petani menjual hasil produksi melalui pasar lelang, peran ketua kelompok, dan harga jual cabai merah dalam keefektifan lembaga pasar lelang.

Kriteria pengujian

Dengan menggunakan software SPSS 13.0 for Windows maka dapat dilakukan analisis sebagai berikut:

1) $R$ square atau koefisien determinasi menunjukkan persen variabel dependen yang dapat diterangkan oleh variabel independen. Untuk jumlah variabel independen yang lebih dari 2 maka digunakan adjusted $R$ square.

2) Dari uji ANOVA atau $F$ test untuk mengetahui apakah variabel independen secara bersamasama berpengaruh terhadap variabel dependen, dapat diambil kesimpulan jika nilai sig $<0,05$ maka variabel independen secara bersama-sama berpengaruh terhadap variabel dependen.

3) Uji t untuk mengetahui ada tidaknya pengaruh masing-masing variabel independen terhadap variabel dependen, maka pengambila keputusan adalah sebagai berikut (taraf signifikansi $\alpha=$ $0,05)$ :

Nilai signifikansi $<\alpha$ maka Ho ditolak

Nilai signifikansi $>\alpha$ maka Ho diterima

\section{HASIL PENELITIAN DAN PEMBAHASAN}

Keefektifan adalah keberhasilan dari tujuan atau perbandingan antara tingkat pencapaian tujuan dengan rencana yang telah disusun sebelumnya. Konsep keefektifan memiliki makna yang berbeda dan kriteria yang berbeda-beda tergantung pada kerangka acuan yang digunakan serta situasi dan kondisi wilayah yang akan diteliti. Dalam penelitian ini, keefektifan lembaga pasar lelang di Kecamatan Panjatan Kabupaten Kulon Progo diukur menggunakan 3 komponen, yaitu output lembaga, fleksibilitas lembaga, serta ada tidaknya ketegangan dalam lembaga.

Output lembaga menunjukkan keluaran yang dihasilkan oleh lembaga dari aspek kualitas maupun kuantitas. Yaitu kualitas dari jasa yang dihasilkan oleh organisasi serta kuantitas atau volume dari jasa yang dihasilkan lembaga. Fleksibilitas lembaga atau keluwesan adaptasi dapat diartikan sebagai kemampuan lembaga untuk mengubah prosedur standar operasinya jika lingkungannya berubah untuk mencegah kebekuan terhadap rangsangan lingkungan. Ada tidaknya ketegangan dalam lembaga menggambarkan fakta bahwa para anggota saling menyukai satu sama lain, bekerja sama dengan baik, berkomunikasi sepenuhnya dan secara terbuka, dan dapat mengkoordinasikan usaha kerja mereka.

Keefektifan lembaga pasar lelang cabai merah di Kecamatan Panjatan Kabupaten Kulon Progo dapat dilihat pada Tabel 1. Output lembaga dijelaskan melalui indikator kelayakan harga jual cabai merah, besarnya keuntungan bagi petani, dan jaminan tersalurkannya (terjualnya) semua hasil produksi. Indikator kelayakan harga jual cabai merah memiliki tingkat keefektifan sebesar 78,4\%, meskipun harga cabai terkadang mengalami penurunan namun cabai yang dijual melalui pasar lelang memiliki harga jual yang lebih tinggi dibanding melalui pedagang langsung dan menghilangkan monopoli pedagang. Selain itu pasar lelang dipercaya mampu menjaga harga agar tidak dipermainkan oleh pedagang. Besarnya keuntungan bagi petani memiliki tingkat keefektifan sebesar $76,6 \%$, sebagian besar petani menilai pasar lelang sudah efektif karena lokasinya yang dekat, mudah pelaksanaannya, harga relatif tinggi dan potongan yang relatif rendah sehingga keuntungan lebih besar. Namun ada pula petani yang merasa keuntungan masih belum maksimal karena terkadang belum mampu menutupi biaya yang dikeluarkan saat produksi. Meski demikian petani sadar apabila dijual melalui pedagang pengumpul (tengkulak) justru mereka akan semakin merugi. Indikator terakhir, jaminan tersalurkannya (terjualnya) semua hasil produksi memiliki 
tingkat keefektifan sebesar 76,6\%, pasar lelang sudah memiliki akses yang luas, di Desa Bugel dan Garongan masing-masing sudah memiliki 5 pedagang tetap dalam proses lelang. Dalam setiap pelelangan biasanya terdapat 5 sampai 8 pedagang yang berpartisipasi sehingga seluruh hasil produksi cabai merah hampir selalu terjual.

Fleksibilitas lembaga dijelaskan melalui indikator kelayakan harga jual meskipun mengalami perubahan harga, kesesuaian frekuensi dan waktu pelaksanaan lelang terhadap ketersediaan hasil, kemampuan menyelesaikan masalah ketika ada pedagang yang mangkir dalam pembayaran, dan keadilan bagi petani dalam menggilir lokasi pelelangan. Indikator kelayakan harga jual meskipun mengalami perubahan harga memiliki tingkat keefektifan sebesar 78,4\%. Harga jual cabai merah memang selalu berubah-ubah sesuai ketersediaan produksi, kualitas cabai, dan kondisi pasar. Namun pasar lelang tetap dapat menyesuaikan kondisi tersebut sehingga keputusan harga tidak terlalu merugikan petani. Salah satu tindakan konkrit yaitu pada tahun 2013 pasar lelang di Kelompok Tani Bangun Karyo, Desa Garongan telah membuat aturan adanya harga dasar cabai merah yang mengharuskan pedagang melelang dengan harga diatas harga dasar. Hal ini dilakukan untuk mengantisipasi harga yang terlalu anjlok. Indikator kesesuaian frekuensi dan waktu pelaksanaan lelang terhadap ketersediaan hasil memiliki tingkat keefektifan sebesar $60,5 \%$. Saat bukan musim panen pasar lelang tidak buka, saat produksi sedikit biasanya pasar lelang buka tiga kali dalam seminggu, dan saat panen raya pasar bisa buka hampir setiap hari untuk menampung semua hasil produksi petani. Hal tersebut menjamin semua hasil produksi petani dapat tersalurkan dan kebutuhan pedagang akan cabai merah yang tidak sedikit pun dapat tercukupi. Indikator kemampuan menyelesaikan masalah ketika ada pedagang yang mangkir dalam pembayaran memiliki tingkat keefektifan sebesar 55,75\%. Hasil ini menunjukkan bahwa pasar lelang cukup fleksibel dalam menghadapi masalah pembayaran. Pasar lelang memang memberikan toleransi kepada pedagang untuk tidak langsung membayar setelah diumumkan menjadi pemenang lelang karena pengurus menyadari sulit untuk menyediakan uang jumlah besar dalam waktu singkat. Hal tersebut yang menyebabkan pedagang sering lambat dalam membayar. Namun pasar lelang sudah mampu mengatasi dengan membuat hukuman bagi pedagang yang mangkir. Pada kelompok tani Bangun Karyo Desa Garongan, pedagang diberi toleransi untuk membayar maksimal 3 hari sejak pelelangan. Apabila melanggar maka pedagang tersebut mendapatkan hukuman tidak diizinkan mengikuti lelang berikutnya sampai dia membayar lunas. Sedangkan pada kelompok tani Gisik Pranaji Desa Bugel, pedagang diberi toleransi untuk membayar maksimal 2 kali tunggakan. Apabila melanggar maka pedagang tersebut akan diberi hukuman tidak diizinkan mengikuti lelang lagi. Indikator fleksibilitas yang terakhir yaitu keadilan bagi petani dalam menggilir lokasi pelelangan memiliki tingkat keefektifan sebesar $45 \%$. Hal ini menunjukkan bahwa pasar lelang tidak terlalu fleksibel dalam hal pergiliran pasar lelang. Pada beberapa pasar lelang ada yang menerapkan lokasi pelelangan yang bergilir dalam satu desa. Maksudnya pengumpulan hasil produksi oleh petani dilakukan pada masing-masing dusun, namun proses pelelangan oleh pedagang dilakukan pada satu lokasi saja untuk memudahkan administrasi dan pasar mampu menyediakan cabai merah dalam jumlah yang cukup banyak. Kemudian untuk menghindari adanya perasaan tidak adil bagi petani antar dusun proses pelalangan dilakukan bergilir pada masing-masing dusun. Namun ada juga beberapa daerah yang melakukan proses lelang secara individu per dusun sehingga membutuhkan pengurus pasar lelang yang lebih banyak.

Ada tidaknya ketegangan dalam lembaga dijelaskan melalui indikator hubungan baik antar anggota kelompok, hubungan baik antara anggota dengan pengurus pasar lelang, keadilan pembagian hasil penjualan, perasaan suka dengan kinerja pengurus pasar lelang, dan persetujuan anggota terhadap keputusan-keputusan yang diambil pengurus. Indikator hubungan baik antar anggota kelompok memiliki tingkat keefektifan sebesar 85,6\%, hubungan kekeluargaan antar petani sangat kental sehingga mereka hidup rukun bersama dan jarang sekali terjadi konflik dengan sesama petani dalam kelompok. Indikator hubungan baik antara anggota dengan pengurus pasar lelang memiliki tingkat keefektifan sebesar $85,4 \%$, tingginya angka ini karena pasar lelang dikelola sendiri oleh kelompok tani setempat dengan kepengurusan dari anggota kelompok tani itu sendiri sehingga kekeluargaan, keterbukaan, dan kepercayaan anggota semakin besar. Indikator keadilan pembagian hasil penjualan memiliki tingkat keefektifan sebesar 
Tabel 1. Keefektifan Lembaga Pasar Lelang Cabai Merah

\begin{tabular}{|c|c|c|c|c|}
\hline No. & Indikator & $\begin{array}{c}\text { Interval } \\
\text { Skor }\end{array}$ & $\begin{array}{c}\text { Skor } \\
\text { Rerata }\end{array}$ & $\begin{array}{c}\text { Tingkat } \\
\text { Keefektifan (\%) }\end{array}$ \\
\hline \multicolumn{5}{|c|}{ Output lembaga } \\
\hline & Besarnya keuntungan bagi petani. & $0-5$ & 3,83 & 76,60 \\
\hline & Jaminan tersalurkannya (terjualnya) semua hasil produksi. & $0-5$ & 3,83 & 76,60 \\
\hline & Kelayakan harga jual cabai merah. & $0-5$ & 3,92 & 78,40 \\
\hline Juml & & $0-15$ & 11,58 & 77,20 \\
\hline \multicolumn{5}{|c|}{ Fleksibilitas lembaga / keluwesan adaptasi } \\
\hline & $\begin{array}{l}\text { Kesesuaian frekuensi dan waktu pelaksanaan lelang terhadap } \\
\text { ketersediaan hasil. }\end{array}$ & $0-4$ & 2,42 & 60,50 \\
\hline 2. & Kelayakan harga jual meskipun mengalami perubahan harga. & $0-5$ & 3,92 & 78,40 \\
\hline 3. & Keadilan bagi petani dalam menggilir lokasi pelelangan. & $0-4$ & 1,80 & 45,00 \\
\hline & $\begin{array}{l}\text { Kemampuan menyelesaikan masalah ketika ada pedagang yang } \\
\text { mangkir dalam pembayaran. }\end{array}$ & $0-4$ & 2,23 & 55,75 \\
\hline Juml & & $0-17$ & 10,37 & 61,00 \\
\hline \multicolumn{5}{|c|}{ Ada tidaknya ketegangan dalam lembaga } \\
\hline & Hubungan baik antar anggota kelompok. & $0-5$ & 4,28 & 85,60 \\
\hline & Hubungan baik antara anggota dengan pengurus pasar lelang. & $0-5$ & 4,27 & 85,40 \\
\hline & Perasaan suka dengan kinerja pengurus pasar lelang. & $0-5$ & 4,12 & 82,40 \\
\hline & $\begin{array}{l}\text { Persetujuan anggota terhadap keputusan-keputusan yang diambil } \\
\text { pengurus. }\end{array}$ & $0-6$ & 4,03 & 67,17 \\
\hline & Keadilan pembagian hasil penjualan. & $0-5$ & 4,18 & 83,60 \\
\hline Juml & & $0-26$ & 20,88 & 80,31 \\
\hline Tota & & $0-58$ & 42,83 & 73,84 \\
\hline
\end{tabular}

Sumber: Analisis Data Primer Tahun 2014

$83,6 \%$, sistem pembagian hasil penjualan yaitu dengan melakukan pemotongan harga sebesar Rp100 sampai Rp300 per kg cabai merah tergantung tinggi rendahnya harga jual. Hasil potongan harga tersebut nantinya sebagian digunakan untuk upah pengurus atau pekerja dan sebagian dimasukkan dalam kas kelompok. Indikator perasaan suka dengan kinerja pengurus pasar lelang memiliki tingkat keefektifan sebesar $82,4 \%$, anggota menilai pengurus pasar lelang sudah bekerja dengan baik, rajin, ulet, jujur, tegas, disiplin, konsisten, kerjasama bagus, terbuka dan selama ini belum ada kasus kecurangan atau korupsi yang dilakukan oleh pengurus pasar lelang. Dan indikator terakhir yaitu persetujuan anggota terhadap keputusan-keputusan yang diambil pengurus memiliki tingkat keefektifan $67,17 \%$, umumnya anggota setuju dengan keputusan yang diambil pengurus karena biasanya keputusan merupakan hasil musyawarah bersama.

Berdasarkan Tabel 2 dapat diketahui bahwa sejumlah 53 orang $(88,33 \%)$ petani anggota menilai lembaga pasar lelang cabai merah memiliki keefektifan yang tinggi dengan skor 38 sampai 55. Sedangkan 7 orang $(11,67 \%)$ petani menilai lembaga pasar lelang cabai merah memiliki keefektifan yang sedang dengan skor 19 sampai 37. Tidak ada petani yang
Tabel 2. Sebaran Keefektifan Lembaga Pasar Lelang Cabai Merah

\begin{tabular}{clrr}
\hline No. & Kategori (skor) & $\begin{array}{c}\text { Jumlah } \\
\text { (orang) }\end{array}$ & $\begin{array}{r}\text { Persentase } \\
(\%)\end{array}$ \\
\hline 1. & Rendah (0-18) & 0 & 0,00 \\
2. & Sedang (19-37) & 7 & 11,67 \\
3. & Tinggi (38-55) & 53 & 88,33 \\
\hline Jumlah & $\mathbf{6 0}$ & $\mathbf{1 0 0 , 0 0}$ \\
\hline
\end{tabular}

Sumber: Analisis Data Primer Tahun 2014

menilai lembaga pasar lelang cabai merah memiliki keefektifan yang rendah ( $0 \%)$. Hal ini berarti sebagian besar petani menilai lembaga pasar lelang cabai merah memiliki keefektifan yang tinggi dan tidak ada petani yang beranggapan bahwa pasar lelang tidak efektif. Skor tertinggi dari ketiga komponen tersebut diperoleh pada ada tidaknya ketegangan dalam lembaga yaitu sebesar $80,31 \%$, disusul pada komponen output lembaga yaitu sebesar $77,20 \%$, dan komponen fleksibilitas lembaga sebesar $61 \%$.

Hipotesis pertama (Ha) pada penelitian ini adalah diduga lebih dari $50 \%$ petani memiliki persepsi bahwa lembaga pasar lelang cabai merah memiliki keefektifan yang tinggi. Untuk membuktikan hipotesis pertama maka dilakukan uji proporsi sebagai berikut : 
Z hitung $=\frac{\frac{x}{n}-P o}{\sqrt{\frac{P o(1-P o)}{n}}}$

Keterangan:

$\mathrm{x}$ : Jumlah sampel petani yang menyebutkan lembaga pasar lelang memiliki keefektifan yang tinggi

$\mathrm{n} \quad$ : Jumlah keseluruhan petani sampel

Po : Keofisien keyakinan (50\%)

Tingkat signifikansi pada $\alpha=0,05(5 \%), \mathrm{n}=60$

Kriteria pengujian:

Z hitung $>$ Z tabel : Ho ditolak, Ha diterima

$\mathrm{Z}$ hitung $\leq \mathrm{Z}$ tabel : Ho diterima, Ha ditolak

$Z$ hitung $=\frac{\frac{\frac{58}{60}-0,5}{\sqrt{\frac{0,5(1-0,5)}{60}}}}{\text {. }}$

$Z$ hitung $=5,938574$

$\mathrm{Z}$ tabel $=-1,645$

$\mathrm{Z}$ hitung $>\mathrm{Z}$ tabel: Ho ditolak, Ha diterima

Berdasarkan hasil perhitungan menggunakan uji proporsi didapatkan hasil bahwa $\mathrm{Z}$ hitung sebesar 5,938574 sedangkan $Z$ tabel -1,645 sehingga Ho ditolak dan Ha diterima. Hal ini berarti sebagian besar petani (>50\%) petani di Kecamatan Panjatan Kabupaten Kulon Progo memiliki persepsi bahwa lembaga pasar lelang cabai merah memiliki keefektifan yang tinggi.

Berdasarkan Tabel 3 dapat diketahui bahwa nilai signifikansi variabel tingkat pendidikan adalah 0,050 , nilai signifikansi variabel sikap petani anggota adalah 0,000 , dan nilai signifikansi variabel peran ketua kelompok adalah 0,017. Ketiga variabel tersebut memiliki nilai signifikansi lebih kecil dari taraf signifikansi yaitu $\alpha=0,05$, sehingga ketiga variabel berpengaruh nyata terhadap keefektifan lembaga pasar lelang. Dari hasil analisis regresi linear berganda juga diperoleh nilai Adjusted square sebesar 0,39 yang menunjukkan bahwa sebesar 39\% variabel keefektifan lembaga pasar lelang dapat dijelaskan oleh variabel tingkat pendidikan, sikap petani anggota, dan variabel peran ketua kelompok. Sedangkan sisanya $61 \%$ dijelaskan oleh faktor-faktor lain di luar model. Nilai F hitung sebesar 13,552 dan F tabel sebesar 4,016, dari hasil uji dapat dilihat bahwa $\mathrm{F}$ hitung $>\mathrm{F}$ tabel, maka dapat disimpulkan bahwa Ho ditolak dan Ha diterima. Variabel tingkat pendidikan, sikap anggota terhadap lembaga pasar lelang, dan peran ketua kelompok secara bersama-sama berpengaruh nyata terhadap keefektifan lembaga pasar lelang dengan nilai signifikansi $<0,05$.

Berdasarkan Tabel 6.4 dapat diketahui bahwa independent variable yang signifikan adalah tingkat pendidikan (X2), sikap anggota (X3), dan peran ketua kelompok (X5), sedangkan independent variable yang lain yaitu umur, motivasi petani, dan harga jual cabai merah tidak berpengaruh nyata terhadap keefektifan lembaga pasar lelang cabai merah karena nilai signifikansinya $>0,05$. Dari faktor-faktor tersebut maka dapat diperoleh persamaan regresi sebagai berikut:

$\mathrm{Y}=12,901-0,505 \mathrm{X} 2+0,353 \mathrm{X} 3+0,250 \mathrm{X} 5$

Keterangan :

$\mathrm{Y}=$ keefektifan lembaga pasar lelang cabai merah

$\mathrm{X} 2$ = tingkat pendidikan petani

$\mathrm{X} 3$ = sikap petani anggota terhadap lembaga pasar lelang

X5 = peran ketua kelompok

Tabel 3. Hasil Analisis Regresi Linier Berganda Faktor-Faktor yang Diduga Mempengaruhi Keefektifan Lembaga Pasar Lelang Cabai Merah (Model 4)

\begin{tabular}{llcccc}
\hline No. & \multicolumn{1}{c}{ Variabel } & $\begin{array}{c}\text { Koefisien } \\
\text { Regresi (B) }\end{array}$ & t Hitung & Sig & Ket \\
\hline 1. $\quad$ Tingkat Pendidikan (X2) & $-0,505$ & $-2,004$ & 0,050 & $*$ \\
2. $\quad$ Sikap Anggota (X3) & 0,353 & 4,875 & 0,000 & $*$ \\
3. $\quad$ Peran Ketua Kelompok (X5) & 0,250 & 2,759 & 0,008 & $*$ \\
\hline Konstanta & 12,901 & & & \\
R square & 0,421 & & & \\
Adjusted square & 0,390 & & & \\
F hitung & 13,552 & & & \\
F tabel & 4,016 & & & \\
\hline
\end{tabular}

Keterangan: *signifikansi pada tingkat kesalahan 5\%; NS: Non Signifikan

Sumber: Analisis Data Primer Tahun 2014 
Berikut ini akan dibahas hasil uji hipotesis masing-masing faktor yang berpengaruh nyata terhadap keefektifan lembaga pasar lelang cabai merah yang merupakan hasil analisis regresi berganda (Model 4).

\section{Tingkat Pendidikan}

Berdasarkan Tabel 3 diketahui bahwa nilai koefisien regresi untuk variabel tingkat pendidikan adalah sebesar $-0,505$ dengan nilai signifikansi 0,050 . Variabel tingkat pendidikan memiliki nilai $t$ hitung sebesar 2,004 dengan $t$ tabel sebesar 2,001. Nilai t hitung lebih besar dari t tabel sehingga hipotesis diterima yang artinya hipotesis tingkat pendidikan berpengaruh nyata terhadap keefektifan lembaga pasar lelang. Berdasarkan hasil analisis regresi linear berganda, diperoleh persamaan regresi sebagai berikut:

$$
\mathrm{Y}=12,901-0,505 \mathrm{X} 2
$$

Keterangan :

$\mathrm{Y}=$ keefektifan lembaga pasar lelang cabai merah

$\mathrm{X} 1$ = tingkat pendidikan petani

Persamaan regresi tersebut jika disajikan dalam grafik adalah sebagai berikut :

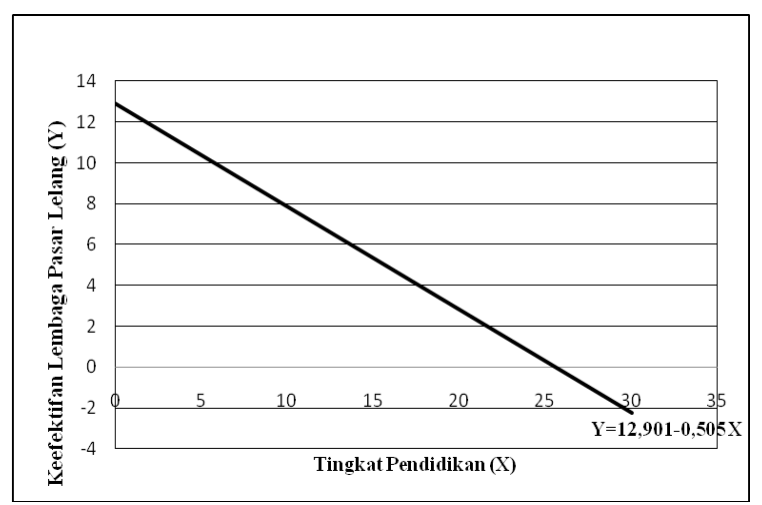

Gambar 2. Grafik Pengaruh Tingkat Pendidikan Terhadap Keefektifan Lembaga Pasar Lelang

Dari Gambar 2 dapat diketahui bahwa variabel tingkat pendidikan berpengaruh negatif terhadap keefektifan lembaga pasar lelang. Nilai koefisien regresi 0,505 menunjukkan bahwa setiap penambahan satu nilai variabel tingkat pendidikan (X2) maka nilai keefektifan lembaga (Y) akan berkurang sebesar 0,505 .
Dengan demikian dapat disimpulkan bahwa semakin tinggi tingkat pendidikan petani maka lembaga pasar lelang semakin tidak efektif. Begitu pula sebaliknya semakin rendah tingkat pendidikan petani maka lembaga pasar lelang semakin efektif. Tingkat pendidikan yang berpengaruh negatif ini dapat terjadi karena beberapa petani yang berpendidikan tinggi memiliki orientasi ekonomi yang tinggi pula sehingga mereka terkadang tidak menjual seluruh hasil produksi melalui pasar lelang namun mencari alternatif pasar dengan harga yang lebih tinggi. Selain itu, untuk menjadi anggota pasar lelang tidak harus memiliki latar belakang pendidikan yang tinggi karena pelaksanaan lelang yang relatif murah, anggota cukup membawa hasil produksi ke pasar lelang dan menunggu hasil penjualan di rumah tanpa harus ikut mensortir, melakukan tawar menawar harga, ataupun mencari pedagang. Fasilitas yang disediakan pengurus sudah sangat mempermudah anggota dalam pemasaran. Sehingga biasanya petani yang tingkat pendidikannya relatif rendah justru selalu menjual hasil produksi melalui pasar lelang karena tidak mempunyai jaringan pemasaran selain pasar lelang dan tengkulak.

\section{Sikap Petani Anggota}

Berdasarkan Tabel 3 diketahui bahwa nilai koefisien regresi untuk variabel sikap petani anggota adalah sebesar 0,353 dengan nilai signifikansi 0,000. Variabel sikap petani anggota memiliki nilai t hitung sebesar 4,875 dengan $t$ tabel sebesar 2,001. Nilai $\mathrm{t}$ hitung lebih besar dari $\mathrm{t}$ tabel sehingga hipotesis diterima yang artinya hipotesis sikap petani anggota berpengaruh nyata terhadap keefektifan lembaga pasar lelang. Berdasarkan hasil analisis regresi linear berganda, diperoleh persamaan regresi sebagai berikut :

$$
\mathrm{Y}=12,901+0,353 \mathrm{X} 3
$$

Keterangan :

$\mathrm{Y}=$ keefektifan lembaga pasar lelang cabai merah

$\mathrm{X} 3$ = sikap petani angggota terhadap lembaga pasar lelang

Persamaan regresi tersebut jika disajikan dalam grafik adalah sebagai berikut : 


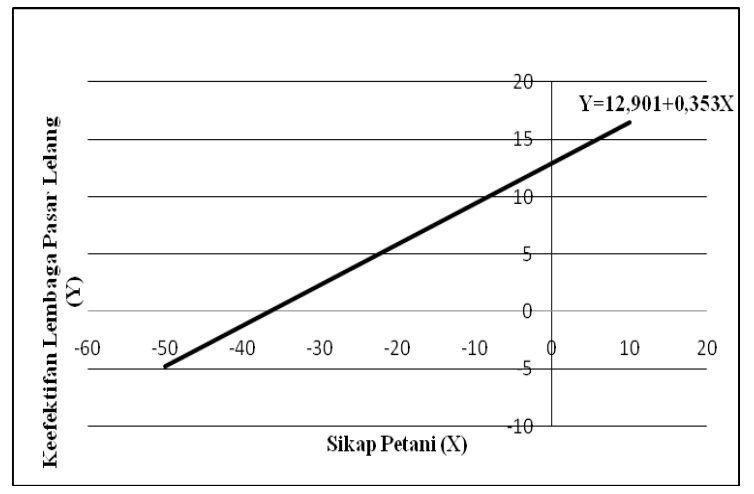

Gambar 3. Grafik Pengaruh Sikap Petani Terhadap Keefektifan Lembaga Pasar Lelang

Dari Gambar 3 dapat diketahui bahwa variabel sikap petani anggota berpengaruh positif terhadap keefektifan lembaga pasar lelang. Nilai koefisien regresi 0,353 menunjukkan bahwa setiap penambahan satu nilai variabel sikap petani anggota (X3) maka nilai keefektifan lembaga (Y) akan meningkat sebesar 0,353 .

Dengan demikian dapat disimpulkan bahwa semakin positif sikap petani anggota terhadap lembaga pasar lelang maka lembaga pasar lelang akan semakin efektif. Tingkat sikap yang berpengaruh searah ini terjadi karena petani yang (kognitif) pengetahuannya positif terhadap pasar lelang maka (afektif) perasaannya terhadap pasar lelang pun menjadi semakin positif sehingga kecenderungan bertindak (konatif) pun semakin positif terhadap lembaga pasar lelang. Kecenderungan bertindak petani ke arah positif lah yang menyebabkan lembaga pasar lelang semakin efektif.

\section{Peran Ketua Kelompok}

Berdasarkan Tabel 3 diketahui bahwa nilai koefisien regresi untuk variabel peran ketua kelompok adalah sebesar 0,250 dengan nilai signifikansi 0,008. Variabel peran ketua kelompok memiliki nilai thitung sebesar 2,759 dengan $\mathrm{t}$ tabel sebesar 2,001. Nilai thitung lebih besar dari t tabel sehingga hipotesis diterima yang artinya hipotesis peran ketua kelompok berpengaruh nyata terhadap keefektifan lembaga pasar lelang. Berdasarkan hasil analisis regresi linear berganda, diperoleh persamaan regresi sebagai berikut:

$$
\mathrm{Y}=12,901+0,250 \mathrm{X} 5
$$

\section{Keterangan :}

$\mathrm{Y}=$ keefektifan lembaga pasar lelang cabai merah

$\mathrm{X} 5=$ peran ketua kelompok
Persamaan regresi tersebut jika disajikan dalam grafik adalah sebagai berikut :

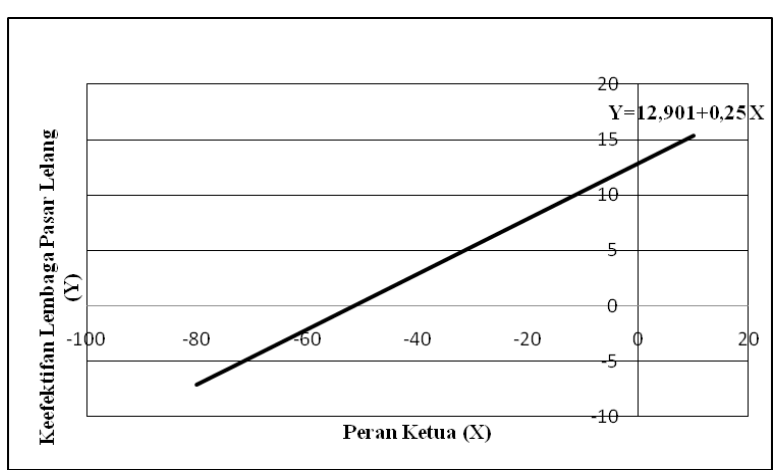

Gambar 4. Grafik Pengaruh Peran Ketua Kelompok

Terhadap Keefektifan Lembaga Pasar Lelang

Dari Gambar 4 dapat diketahui bahwa variabel peran ketua kelompok berpengaruh positif terhadap keefektifan lembaga pasar lelang. Nilai koefisien regresi 0,250 menunjukkan bahwa setiap penambahan satu nilai variabel peran ketua kelompok (X5) maka nilai keefektifan lembaga (Y) akan meningkat sebesar 0,250.

Dengan demikian dapat disimpulkan bahwa semakin tinggi peran ketua kelompok tani maka lembaga pasar lelang akan semakin efektif. Tingkat peran ketua yang berpengaruh positif ini terjadi karena ketua kelompok merupakan tokoh tani yang disegani dan menjadi panutan oleh petani anggota sehingga dengan perannya sebagai motivator, komunikator, dan fasilitator yang tinggi maka lembaga pasar lelang akan semakin efektif.

\section{KESIMPULAN}

1. Keefektifan lembaga pasar lelang cabai merah di Kecamatan Panjatan Kabupaten Kulon Progo tergolong efektif di mana 53 petani $(88,33 \%)$ menilai lembaga pasar lelang memiliki keefektifan tinggi.

2. Faktor-faktor yang berpengaruh secara nyata terhadap keefektifan lembaga pasar lelang cabai merah yaitu tingkat pendidikan, sikap petani anggota terhadap lembaga pasar lelang, dan peran ketua kelompok. Semakin tinggi tingkat pendidikan, maka lembaga pasar lelang semakin tidak efektif. Semakin positif sikap petani, maka lembaga pasar lelang semakin efektif. Semakin tinggi peran ketua kelompok, maka lembaga pasar lelang semakin efektif. 


\section{DAFTAR PUSTAKA}

Anugrah, I. S. 2004. Pengembangan Sub Terminal Agribisnis (STA) dan pasar lelang komoditas pertanian dan permasalahannya. Pusat Penelitian dan Pengembangan Sosial Ekonomi Pertanian. Forum Penelitian Agro Ekonomi 22 (2): 102-112.

Damoma, R., I Dewa, G. R. S. dan I Gusti, A. A. L. A. 2013. Kajian terhadap implementasi pasar lelang komoditi agro pada Dinas Perindustrian dan Perdagangan Provinsi Bali. E-Jurnal Agribisnis dan Agrowisata 2: 204-213.

Hartono, S., J.H Mulyo, Masyhuri, D. Hadidarwanto dan Sinarhadi. 1996. Riset Desain Rintisan Pengembangan Pasar Lelang Komoditas Perkebunan Melalui Koperasi. Fakultas Pertanian UGM, Yogyakarta.

Martius, E. 2008. Kemitraan agribisnis untuk memberdayakan ekonomi rakyat. Jurnal Agribisnis Kerakyatan Fakultas Pertanian. Universitas Andalas.
Monoarfa, Heryanto. 2012. Efektivitas dan efisiensi penyelenggaraan pelayanan publik: Suatu tinjauan kinerja lembaga pemerintahan. Jurnal Pelangi Ilmu 05 (01)

Mulyasa. 2003. Manajemen Berbasis Sekolah, Konsep, Strategi, dan Implementasi. PT Remaja Rosdakarya, Bandung.

Rintuh, Cornelis dan Miar. 2003. Kelembagaan dan Ekonomi Rakyat. Direktorat Pembinaan Penelitian dan Pengabdian pada Masyarakat, Direktorat Jenderal Pendidikan Tinggi, Palangka Raya.

Steers, Richard M. 1985, Efektivitas Organisasi (Kaidah Perilaku), Erlangga, Jakarta.

Supriyanto, Subejo, Ageng, S. H., Sri, P. W., Dyah, W. U., Siwi, I. D., dan Lailia, D. W. 2012. Strategi Adaptasi Petani Terhadap Perubahan Iklim. Laboratorium Pengkajian Masalah Sosial dalam Pertanian Program Studi Penyuluhan dan Komunikasi Pertanian UGM. Yogyakarta 